\title{
Analyses of the development and glycoproteins present in the ovarian follicles of Poecilia vivipara (Cyprinodontiformes, Poeciliidae) ${ }^{1}$
}

\author{
Thiago L. Rocha ${ }^{2}$, Áureo T. Yamada ${ }^{3}$, Renata Mazaro e Costa ${ }^{4}$ \\ and Simone M.T. Sabóia-Morais ${ }^{2 *}$
}

\begin{abstract}
Rocha T.L., Yamada A.T., Mazaro e Costa R. \& Sabóia-Morais S.M.T. 2011. Analyses of the development and glycoproteins present in the ovarian follicles of Poecilia vivipara (Cyprinodontiformes, Poeciliidae). Pesquisa Veterinária Brasileira 31(1):87-93. Laboratório de Comportamento Celular, Departamento de Morfologia, Instituto de Ciências Biológicas, Universidade Federal de Goiás, Campus II, ICB IV, Cx. Postal 131, Goiânia, GO 74001-970, Brazil. E-mail: simonesaboias@gmail.com

The morphofunctional aspects of oogenesis of Poecilia vivipara were studied aiming to understand the reproductive biology and development of species with internal fertilization, particularly those belonging to the family Poeciliidae. The stages of gonadal maturation and follicular development were characterized using mesoscopic, histological, histochemical, and lectin cytochemical analyses. Through mesoscopic evaluation the ovarian development was classified in six phases of development: immature, in maturation I, in maturation II, mature I, mature II, and post-spawn. Based on microscopic examination of the ovaries, we identified the presence of oocytes types I and II during the previtellogenic phase and types III, IV, and V during the vitellogenic phase. As oogenesis proceeded the oocyte cytosol increased in volume and presented increased cytoplasmic granule accumulation, characterizing vitellogenesis. The zona radiata (ZR) increased in thickness and complexity, and the follicular epithelium, which was initially thin and consisting of pavimentous cells, in type III oocytes exhibited cubic simple cells. The histochemical and cytochemical analyses revealed alterations in the composition of the molecular structures that form the ovarian follicle throughout the gonadal development. Our study demonstrated differences in the female reproductive system among fish species with internal and external fertilization and we suggest $P$. vivipara can be used as experimental model to test environmental toxicity.
\end{abstract}

INDEX TERMS: Ovarian development, protein, histology, reproduction, ovoviviparity.

RESUMO.- [Análise do desenvolvimento e das glicoproteínas presentes nos folículos ovarianos de Poecilia vivipara (Cyprinodontiformes, Poeciliidae).] Os apectos morfofuncionais da oogênese do Poecilia vivipara foram

\footnotetext{
${ }^{1}$ Received on August 24, 2009.

Accepted for publication on 09876543210987654321

${ }^{2}$ Laboratório de Comportamento Celular, Departamento de Morfologia, Instituto de Ciências Biológicas, Universidade Federal de Goiás (UFG), Campus II, ICB IV, Cx. Postal 131, Goiânia, GO 74001-970, Brazil. "Corresponding author: simonesaboias@gmail.com

${ }^{3}$ Laboratório de Citoquímica e Imunocitoquímica, Departamento de Histologia e Embriologia, Instituto Biológico, Universidade de Campinas (Unicamp), Campinas, SP, Brazil. E-mail: yamadat@unicamp.br

${ }^{4}$ Laboratório de Fisiologia e Farmacologia da Reprodução, Departamento de Ciências Fisiológicas, Instituto de Ciências Biológicas, UFG, Goiânia-GO, Brazil. E-mail: mazaro@icb.ufg.br
}

estudados nesse trabalho. Esse estudo contribuiu para o aprimoramento das informações sobre a biologia reprodutiva e do desenvolvimento de espécies com fecundação interna, em especial aquelas pertencentes à família Poecilidae. Para tanto, caracterizou-se os estágios de maturação gonadal e desenvolvimento folicular através de análises mesoscópicas, histológicas, histoquímicas e citoquímicas com lectinas. O estudo mesoscópico permitiu a classificação do desenvolvimento ovariano em seis estágios: imaturo, em maturação I, em maturação II, maturo I, maturo II e pós-desova. O exame microscópico dos ovários permitiu a identificação dos oócitos pré-vitelogênicos (OPVt) e vitelogênicos (OVt). Na fase pré-vitelogênese, verificou-se os oócitos tipo I (OI) e tipo II (OII), e na fase vitelogênese, foram encontrados oócitos tipo III (OIII), tipo IV (OIV) e os 
pós-fertilização (OV). Com o avanço da oogênese, o citosol dos oócitos aumentaram em volume, com crescente acúmulo de grânulos citoplasmáticos, caracterizando a vitelogênese. Além disso, a zona radiata (ZR) aumentou de espessura e alterou suas características histocitoquímicas, e o epitélio folicular (EF), inicialmente delgado e constituído por células pavimentosas, nos FOs na fase III tornaram-se cúbico simples. As análises histoquímicas e citoquímicas permitiram diagnosticar alterações na composição molecular das estruturas que formam os FOs ao longo do desenvolvimento gonadal. O presente estudo indica diferenças no sistema reprodutor feminino entre espécies de peixes com fecundação interna e aquelas com fecundação externa e sugere que o $P$. vivipara pode ser usado como modelo experimental em testes de toxicidade ambiental.

TERMOS DE INDEXAÇÃO: Desenvolvimento ovariano, proteína, histologia, reprodução, ovoviviparidade.

\section{INTRODUCTION}

The guppy (Poecilia vivipara, Block \& Schneider 1801), a neotropical euryhaline fish species widely distributed in the Americas, shows sexual dimorphism, internal fertilization, and ovoviviparity (Rocha \& Sabóia-Morais 2007). This species reproduces both in freshwater (0 ppm of salinity) and sea water (20 ppm of salinity). The female size is directly related to salinity and the number of oocytes released per spawning is associated with both the female size and salinity (Sabóia-Morais et al. 1996, Gomes-Jr. \& Monteiro 2007).

Studies on the gonadal development are important to fully understand the reproductive cycle, size at gonadal maturity of females, duration of spawning season, and fertility, as well as to evaluate the general biology of the species in association with its application in order to preserve fish biodiversity (West 1990, Santos et al. 2004, Chellappa et al. 2005). Moreover, these studies provide basic information to understand different reproductive strategies, systematic and phylogenetic patterns to provide support for aquaculture, and researches on ecotoxicology.

Researchers prefer to use females to study the reproductive biology of fish than males. Females are good indicators of the spawning season, since new individuals depend on the quantity and quality of oocytes because the production of spermatozoa is generally high and oocytes determine the synthesis and storage of the nutrients that are necessary for embryo development, such as vitellogenin (Santos et al. 2005). Vitellogenesis promotes the accumulation of yolk protein, which accounts for $80-90 \%$ of the ovary weight, and contributes to oocyte growth (Selman \& Wallace 1989).

Several studies have been carried out aiming at understanding vitellogenesis and the reproductive biology of fish with external fertilization (Brandão et al. 2003, Cognato \& Fialho 2006, Gomes et al. 2007). By contrast, oogenesis and the initial development of species with internal fertilization have not been sufficiently investigated. Thus, this study intended to analyze the characteristics of ovarian follicles at different stages of development in $P$. vivipara, an ovoviviparous neotropical fish species with internal fertilization, as well as its ovarian organization and the composition of glycoconjugates during oogenesis.

\section{MATERIALS AND METHODS}

The protocol (126/2008) of this study was approved by the Medical Research Ethics Committee of Hospital das Clínicas, Universidade Federal de Goiás.

We captured 40 healthy females of $P$. vivipara in tanks located in the School of Veterinary Medicine at the Universidade Federal de Goiás, in Goiânia (16³5’37"S, 49¹6’50" W), Midwestern Region of Brazil, and transported them to the Laboratory of Cellular Behavior, where they were kept for 2 weeks in 50-L tanks containing filtered dechlorinated water. All the animals used in this experiment were fed ad libitum with commercial diet (Tetra, Germany) and the environmental conditions were kept as follows: $\mathrm{pH} 6.9$; temperature $\pm 27^{\circ} \mathrm{C}$; luminosity, 12-hour light-dark natural cycle; and level of ammonia dissolved in water ranging from $0 i \mathrm{l} / \mathrm{L}$ to $0.01 \mathrm{i} / \mathrm{L}$.

At the end of a period of acclimation, the animals had their total length $(\mathrm{cm})$ and weight $(\mathrm{g})$ measured and after being euthanized by hypothermia followed by decapitation (Brasil 2008) they were sectioned ventrally to expose the gonads, which were macroscopically analyzed to determine the stages of gonadal development.

The gonads were collected and weighed to determine the gonadal somatic index (GSI) according to Favaro et al. (2003): GSI = GW / (TW - GW) x 100, where GW = gonad weight $(\mathrm{g})$ and TW = total body weight $(\mathrm{g})$.

To assess the ovarian maturation stages we used a stereoscopic microscope (Metrimpex Hungary/PZO Labrimex) and observed the morphology of the gonads, the distribution of vessels, the staining of oocytes, and the different developmental stages of guppy embryos and larvae. To describe these stages and macroscopically classify the ovarian development of $P$. vivipara we used the ovarian parameters described by Brandão et al. (2003) and Chellappa et al. (2005).

After dissection, the gonads were fixed by immersion in Karnovsky solution for $2 \mathrm{~h}$ (Karnovsky 1965) and divided into three sets: a) 20 specimens were embedded in Paraplast (SEM, USA), cut into $4 \mu \mathrm{m}$-thick sections that were mounted on glass slides, stained with Harris haematoxylin and eosin (HE), and submitted to the following histochemical reactions for the detection of glycoconjugates - Periodic Acid Schiff (PAS) (McManus 1948); PAS + acetylation; PAS + acetylation + saponification (Lillie \& Fullmer 1976); PAS + diastase (Spicer et al. 1967); PAS + Alcian Blue (AB) (Mowry 1956); AB pH 2.5 and $A B$ pH 0.5 (Lev \& Spicer 1964); $A B+$ methylation and $A B$ + methylation + saponification (Spicer \& Lillie 1959); b) 15 specimens were screened using a panel of 10 biotinylated lectins - Soybean Agglutinin (SBA); Erythrina lectin Cristagalli (ECL); Vicia villosa lectin (VVL-B); Solanum tuberosum (potato) lectin (STLB); Lycopersicon esculentum (tomato) lectin (LELB); Phaseolus vulgaris Erythroagglutinin (PHA-E4); Ulex europaeus Agglutinin I (UEA-I); Wheat Germ Agglutinin (WGA); Maack amurensis lectin (MAM); Concanavalin A (CONAI); and the development using streptoavidin-peroxidase (Dako, USA) was performed in the histological sections employing the technique described by Paffaro Jr. et al. (2003); c) 5 specimens were embedded in historesin (Leica, Germany), cut into $0.5 \mu \mathrm{m}$-thick sections that were mounted on glass 
slides, stained with $1 \%$ toluidine blue, $\mathrm{pH} 8.4$, analyzed and photographed using an Olympus B071 photomicroscope. To perform the histochemical analyses and lectin screening we employed mature ovaries containing ovarian follicles at different stages of oogenesis.

Post-spawning ovary sampling was carried out after monitoring fingerlings birth. In this study we adopted the phases of $P$. vivipara development described by Rocha \& Sabóia-Morais (2007).

\section{Body development}

\section{RESULTS}

Poecilia vivipara adult females differ from adult males in the following characteristics: they are silver, generally present extended belly, and higher total body length. In our study, the body weight of females ranged from 0.15 to $0.33 \mathrm{~g}$ $(0.48 \pm 0.41 \mathrm{~g})$, the average body length ranged from 1.50 to $3.57 \mathrm{~cm}(2.44 \pm 0.72 \mathrm{~cm})$, and the average number of embryos per female ranged from 0 to $31(14.66 \pm 10.83)$. We observed a great variation in GSI, from a maximum of 60.46 to a minimum of $0.88(15.02 \pm 5.34)$.

\section{Gonadal development: Macroscopic classification}

After analyzing the oocytes macroscopically, based on their size, color, degree of vascularization, and appearance we classified $P$. vivipara ovaries in six phases of development: immature, in maturation I, in maturation II, mature I, mature II, and post-spawn (Table 1).

\section{Gonadal development: Microscopic classification}

The histological sections of ovarian follicles were microscopically examined allowing the characterization of previtellogenic and vitellogenic oocytes. In the previtellogenic phase, we observed oocytes types I and II and during the vitellogenic phase we found oocytes types III, IV, and V (Table 2; Fig.1A-D, 2A-D). The ZR was not evident in type IV oocytes using conventional techniques, classical histochemical techniques, or cytochemistry with lectins.

Among the histological, histochemical, and cytochemical reactions used in this study, we should highlight the use of $\mathrm{AB} \mathrm{pH} 2.5$ technique to locate and characterize oocytes types I and II.

Table 1. Macroscopic characteristics of Poecilia vivipara ovarian development phases

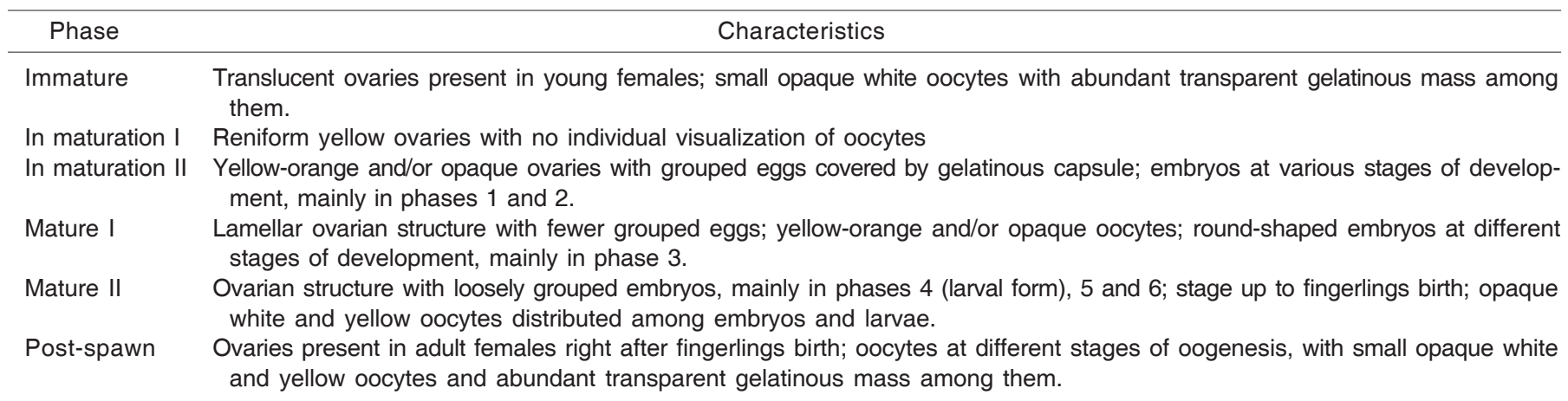

Table 2. Microscopic characteristics of Poecilia vivipara oocytes

Phase/oocyte type Characteristics

Previtellogenic phase

Type I oocytes

Observed in the early stages of oocyte development, present in follicular phase I, usually located close to type II oocytes characterized by a bulky nucleus, almost occupying the whole cytoplasm, absence of the ZR, very thin PHA-E4 positive follicular epithelium formed by pavimentous cells; PAS-non-reactive and $\mathrm{AB} \mathrm{pH}$ 2.5-reactive cytoplasm, presenting small PHA-E4-positive cytoplasmic granules.

Type II oocytes $\quad$ Found in follicular phase II, showing increased cytoplasmic volume and decreased nuclear volume; presence of one or more nucleoli; follicular epithelium still thin and formed by pavimentous cells; initial formation of the ZR with positive reaction to SBA and VVL-B; cytosol was PAS non-reactive, AB pH 2.5, SBA, VVL-B, and PHA-E4 reactive, presenting small $A B$ $\mathrm{pH}$ 2.5-negative cytoplasmic granules

Vitellogenic phase

Type III oocytes

Found in follicular phase III, presenting lipid-rich vesicles in the periphery of the cytoplasm and round nuclei;follicular epithelium exhibiting cubic simple cells, with some stratified regions, surrounded by stromal cells; thick ZR with invaginations of the follicular epithelium; AB pH 2.5-reactive follicular epithelium and ZR; SBA, WGA, and VVL-B-reactive ZR; cytosol was SBA, VVL-B, PHA-E4, WGA and ConA reactive, showing weak reaction to $A B \mathrm{pH} 2.5$, and presenting some $A B \mathrm{pH}$ 2.5-reactive and PAS-non-reactive granules, and others $\mathrm{AB} \mathrm{pH}$ 2.5-non-reactive and PAS-reactive.

Type IV oocytes $\quad$ Observed in follicular phase IV; characterized by abundant cytoplasm and large lipid globules, presenting PAS-reactive and amylase-reactive granules, PAS-reactive cortical alveoli, and yolk globules in the periphery; nuclei and ZR not present; thin follicular epithelium, sometimes lacking, surrounded by ovoid stromal cells; PAS-reactive cytosol showing weak reaction to $\mathrm{AB} \mathrm{pH}$ 2.5; $\mathrm{AB} \mathrm{pH} 2.5$ and $\mathrm{PAS}$-reactive yolk globules; regions with granular appearance reactive to VVL-B, STLB, LELB, WGA, and ConA lectins; UEA-I-non-reactive peripheral cytoplasmic granules.

Type $\mathrm{V}$ oocytes $\quad$ Found in post-fertilization phase; characterized by cortical alveoli merged with the cell membrane and consequent release of granule contents (cortical reaction); eggs in the initial stages of embryonic development. 


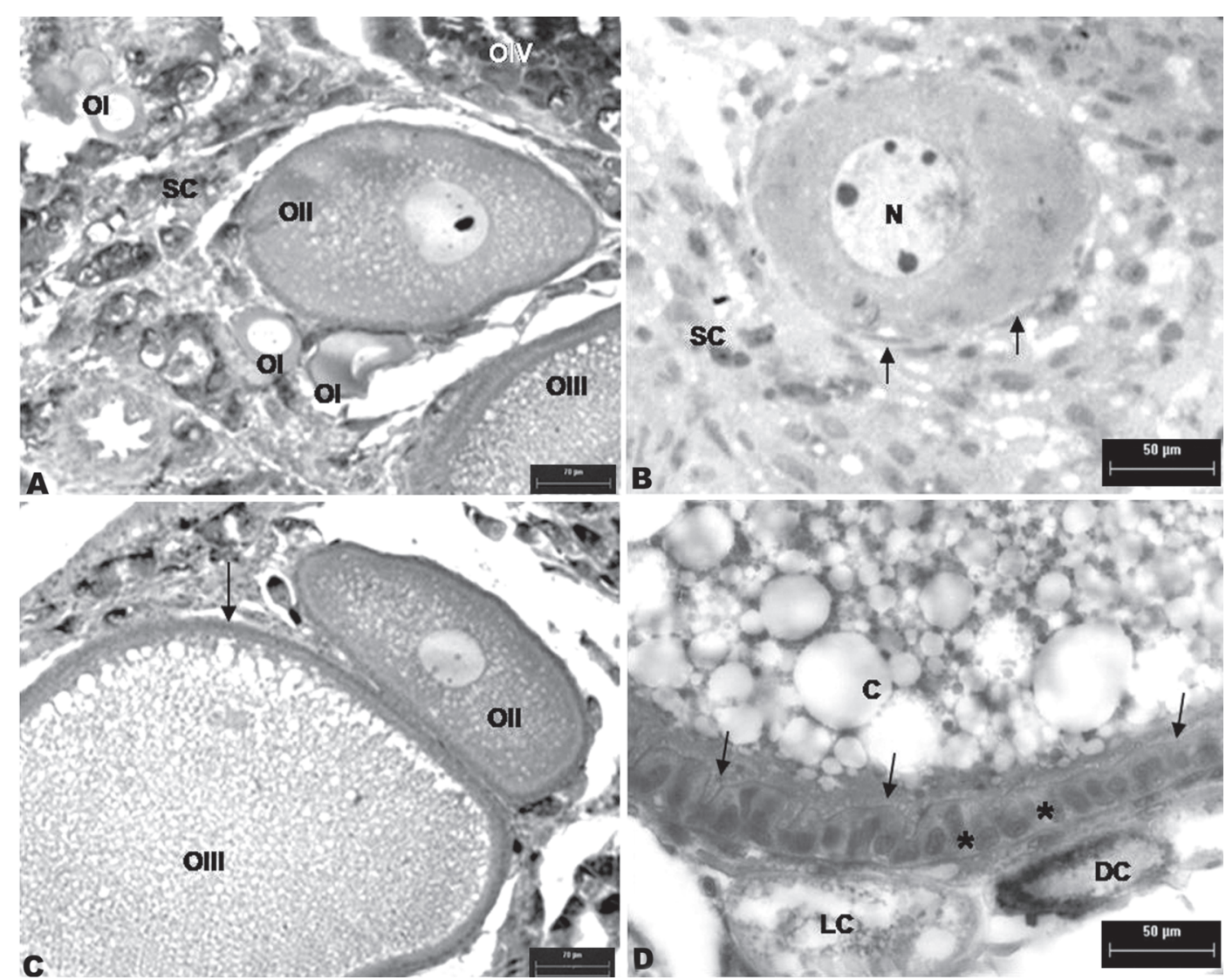

Fig.1. (A) Histological horizontal section of Poecilia vivipara ovary showing stromal cells (SC) and oocytes at different phases of oogenesis: type I (OI), type II (OII), type III (OIII), and type IV (OIV); technique: $\mathrm{PAS}+\mathrm{AB} \mathrm{pH} 2.5$; bar $=50 \mu \mathrm{m}$. (B) Ovarian follicles in phase I, presenting OI with a bulky nucleus $(\mathrm{N})$ containing four nucleoli, pavimentous follicular cells in the periphery (arrows) surrounded by stromal cells (SC); technique: $1 \%$ toluidine blue, $\mathrm{pH} 8.4$; bar $=50 \mu \mathrm{m}$. (C) Ovarian follicles in phases II and III; observe OII nucleus and cytosol as well as OIII cytosol surrounded by thick membrane (arrow); technique: $\mathrm{PAS}+\mathrm{AB} \mathrm{pH} 2.5$; bar $=50 \mu \mathrm{m}$. (D) Details of the ovarian follicle in phase III showing cytosol with some PAS-reactive granules and others $\mathrm{AB} \mathrm{pH}$ 2.5reactive $(C)$, zona radiata (arrow), light cell (LC), and dark cell (DC) next to the follicular epithelium $\left(^{*}\right)$; technique: $\mathrm{PAS}+\mathrm{AB} \mathrm{pH} 2.5$; bar $=50 \mu \mathrm{m}$.

\section{DISCUSSION}

Poecilia vivipara showed great variations in GSI, a characteristic related to the high adaptive capacity of the female body to maintain and transport embryos and larvae up to phase 6 of embryonic and larval development (Rocha \& Sabóia-Morais 2007). When the females carry the larvae in phase 6 , GSI is very high, sometimes accounting for more than $50 \%$ of total body weight. However, the permanence of oocytes at different stages of oogenesis in post-spawning adult females indicates the occurrence of a new reproductive cycle within a short time, which suggests an adaptive advantage of fish that have internal fertilization.

The great morpho-physiological variety of reproductive system presented by female teleosts, reflecting the great diversity of reproductive strategies and differences in development among species (Santos et al. 2006), was observed in this study through the identification of different sets of oocytes, embryos, and larvae occurring simultaneously at the same stage of ovarian development, which characterizes $P$. vivipara as a species that presents superfetation (Reznick et al. 1996).

The molecular events that take place with nuclearcytoplasmic interaction are responsible for complex processes that form the stages of oogenesis (Monroy et al. 1983). The ovarian follicle morphology is characterized by cell groups that constitute follicular cells and theca cells associated with oocytes. According to the process of maturation, there are changes in the behavior of these structural and functional cells (Bachvarova et al. 1992). The tests we carried out showed that guppies have ovarian follicle morphology similar to that of other teleosts. The macroscopic analysis permitted the classification of ovarian maturation of this species into six stages and the microscopic data provided information to divide the development of $P$. vivipara ovarian follicle into five phases.

Several studies have shown differences between the ovarian classification of fish with external fertilization, such as Symphysodon discus (Heckel 1840), Oligosarcus 

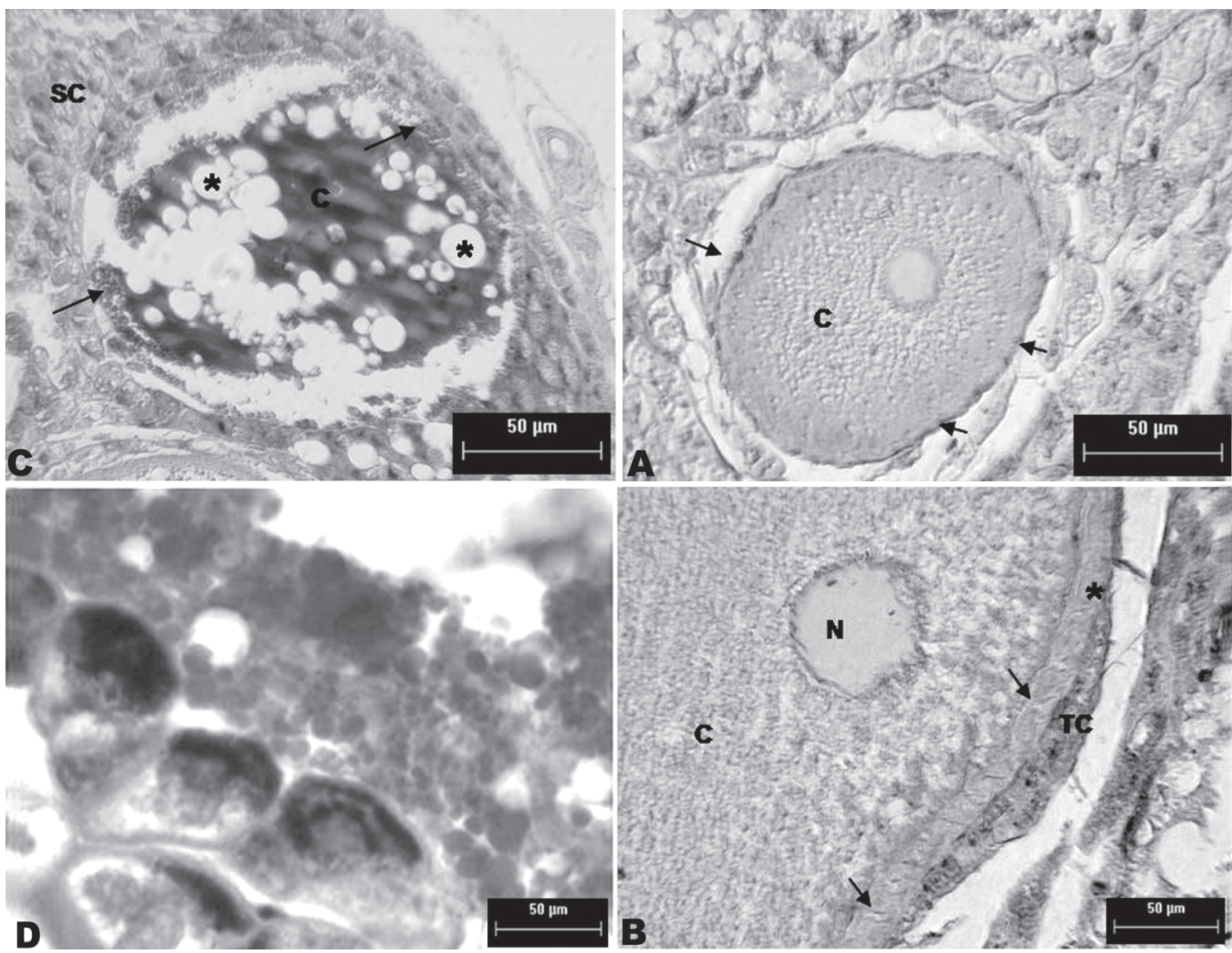

Fig.2. (A) Ovarian follicles in phase III showing the cytosol of type III oocyte (C) and several theca interna cells (arrows) next to the WGA-reactive follicular epithelium; technique: reaction to lectin WGA; bar $=50 \mu \mathrm{m}$. (B) Details of the ovarian follicle in phase III presenting the zona radiata (arrow), cytosol (C), nucleus (N), and theca cell (TC) near the follicular epithelium $\left(^{*}\right)$ of type III oocyte; technique: reaction to lectin WGA; bar $=50 \mu \mathrm{m}$. (C) Ovarian follicles in phase IV showing stromal cells (SC), cytosol with $\mathrm{AB}$ pH 2.5-reactive regions (C), PAS-reactive peripheral granules (arrows), and lipid globules $\left({ }^{*}\right.$ ) in type IV oocyte; technique: PAS $+\mathrm{AB} p H 2,5 ;$ bar $=50 \mu \mathrm{m}$. (D) Details of the periphery of ovarian follicles in phase IV lacking follicular epithelium and presenting stromal cells with $\mathrm{AB}$ pH 2.5-reactive cytoplasmic granules, and oocyte type IV cytosol containing some PAS-reactive granules and some $\mathrm{AB} \mathrm{pH}$ 2.5-reactive ones. $\mathrm{PAS}+\mathrm{AB} \mathrm{pH} \mathrm{2.5}$, bar $=50 \mu \mathrm{m}$.

hepsetus (Cuvier 1829), and Iheringichthys labrosus (Lütken 1874) (Chellappa et al. 2005, Santos et al. 2005, 2006), and those presenting internal fertilization, such as $P$. vivipara. This finding was confirmed in the present study, since the observation of embryos and larvae at different stages of development in this fish species was an important factor in our analysis due to the occurrence of additional stages of ovarian maturation. Nevertheless, further studies on ovoviviparous species are still needed to allow a better understanding of the complex reproductive strategies of these fish species.

The vitellogenesis in teleosts is initiated by the synthesis of vitellogenin in the liver in response to estradiol-17â, its release in the blood stream, and transport to the ovary (Matsubara \& Sawano 1995). Vitellogenin is a highmolecular-weight phosphoglycoprotein, which is incorporated into the oocyte during its maturation and proteolytically cleaved into smaller molecules of proteins of the yolk (Jalabert 2005). The capture of vitellogenin occurs in the intercellular spaces of the follicular cells and later in the oocyte surface by pinocytosis (Cruz-Landim \& Cruz-Höfling 2001).

In this study, during oogenesis in $P$. vivipara, we could observe an increase in both the cytosolic volume of the oocytes and the accumulation of cytoplasmic granules characterizing vitellogenesis. In the cytosol of type I and II oocytes we detected high contents of carboxylic acids and/ or sulphated glycoproteins (GPs) and small amounts of cytoplasmic granules containing $\mathrm{N}$-acetylgalactosamine and/or complex sugars. Also, in the cytosol of type III oocytes we identified the presence of á- and â- $\mathrm{N}$ acetylgalactosamine, $\mathrm{N}$-acetylglucosamine and/or sialic acid, the occurrence of some granules containing carboxylic acids and/or sulphated GPs, and others containing neutral GPs. The cytosol of type IV oocytes showed higher amount of neutral GPs than carboxylic acids and/or sulphated GPs, and in the granular regions we observed á- and â-Nacetylgalactosamine, $\mathrm{N}$-acetylglucosamine, and á-Dmannose or á-D-glucose.

The ZR increased in thickness and complexity as the 
ovarian follicles of the guppies developed and we could also detect an increasing number of invaginations of the ZR in the follicular epithelium. The ovarian follicles presented high contents of á- and â-N-acetylgalactosamine in the ZR in phase II, and á- and â-N-acetylgalactosamine, $\mathrm{N}$-acetylglucosamine and/or sialic acid in phase III. In phase IV, we did not observe the presence of the ZR. The histochemical analysis and cytochemistry with lectins indicated that the ZR of $P$. vivipara is composed of complex sets of GPs with high glycosylation. These molecules probably have species-specific recognition functions in the interaction between gametes. The presence of GPs has been identified in the zona pellucida of different species of mammals (Parillo et al. 2000), and in the ZR of amphibians (Dell et al. 1999), as well as of certain species of fish (Gomes et al. 2007). Besides mediating the sperm-oocyte interaction, these GPs might protect them against physical agents and microorganisms.

According to Agostinho et al. (1987), the ZR controls the passage of substances to the interior part of oocytes during vitellogenesis, protects the oocytes against physical injuries, and, when necessary, promotes the adherence of the eggs to the substrate after spawning. Differences in the features of the ZR, such as macromolecular composition, structure, and thickness, among fish species reflect their adaptation to different ecological conditions (Stehr \& Hawkes 1979, Fausto et al. 2004).

We could detect changes in P. vivipara follicular epithelium during the stages of follicular development. Initially, it was thin and composed of pavimentous cells, but in phase III it was composed of cubic simple cells. The positive reaction to $\mathrm{AB} \mathrm{pH} 2.5$ indicated the presence of acidic sulphated and/or carboxylated GPs. The morphological change observed in the follicular epithelium indicates alteration in its role during oogenesis. In Lophiosilurus alexandri (Steindachner 1877), Barros et al. (2007) reported that these cells synthesize certain glycoconjugates that promote the adherence of the eggs to the substrate when they are secreted on their surface. In the guppies, due to the internal fertilization, there is no adherence of the eggs; therefore, the secretory activity of the follicular epithelium cells in this species is probably important for the mechanical protection of the eggs. We hypothesized that the presence of stratified follicular epithelium in some ovarian follicles indicates their preparation for the next phase of follicular development by increasing the number of epithelial cells, which was confirmed by the presence of these cells during the phases of mitosis in follicular epithelium.

Villecco et al. (2007) analyzed the follicular epithelium of previtellogenic oocytes of Ceratophrys cranwelli and observed the development of two distinct types of cells: clear and dark ones. The dark cells were actively involved in the synthesis of RNAs, which were transferred to the oocytes and subsequently suffered apoptosis. Thus the other cells of the ovarian follicles, in addition to the oocytes, participated in the synthesis of the yolk constituents, providing a fast development of oocytes. We detected similar cells in different stages of $P$. vivipara follicular development, particularly in phase III. This happened because during the reaction to $\mathrm{PAS}+\mathrm{AB} \mathrm{pH} 2.5$ some cells presented $\mathrm{AB} \mathrm{pH}$ 2.5-reactive granules (dark cytoplasm), whereas other cells did not show such a reaction (clear cytoplasm). We believe that this transference of material to the oocytes provides nutrient supplement for its development.

The nutritional supplement provided by the yolk during the early stages of follicular development, associated with the parental care provided by female guppies due to internal fertilization, leads this species to a high degree of adaptive and reproductive success. Therefore, $P$. vivipara can be used as an experimental model in environmental toxicity testing.

Acknowledgments.- To CNPq and FAPESP for the support provided.

\section{REFERENCES}

Agostinho A.A., Barbieri M.C., Barbieri G. \& Agostinho C. 1987. Biologia reprodutiva de Rhinelepis aspera (Agassiz, 1829) (Teleostei, Loricaridae) no rio Paranapanema. II. Estrutura dos ovários e estádios de maturação. Revta Bras. Biol. 47:319-328.

Bachvarova R., Manova K., Packer A.I., Huang E.J. \& Besmer P. 1992. Role of c-kit and its ligand in oocyte growth, p.25-37. In: Hsueh A.J.W. \& Schomberg D.W. (Eds), Ovarian Cell Interactions. Serono, Norwell.

Barros M.D.M., Guimarães-Cruz R.J., Veloso-Júnior V.C. \& Santos J.E. 2007. Reproductive apparatus and gametogenesis of Lophiosilurus alexandri Steindachner (Pisces, Teleostei, Siluriformes). Revta Bras. Zool. 24:213-221.

Brandão C.A.S., Valentim M.F.M. \& Pellegrini-Caramaschi E. 2003. Ovary maturation stages and oocyte features in three species of the neotropical fish Hemiodus (Müller, 1842). Braz. Arch. Biol. Technol. 46:433-441.

Brasil 2008. Lei $n^{\circ} 11.794$, de 8 de outubro de 2008. Regulamenta o inciso VII do § 1ำ do art. 225 da Constituição Federal, estabelecendo procedimentos para o uso científico de animais; revoga a Lei $\mathrm{n}^{\circ}$ 6.638, de 8 de maio de 1979; e dá outras providências. Diário Oficial da União, Brasília, DF, 9 out. Available at <http://www.planalto.gov.br/ ccivil/_Ato2007-2010/2008/Lei/L11794.htm> Access on: Jan. 29, 2009.

Chellappa S., Câmara M.R. \& Verani J.R. 2005. Ovarian development in the Amazonian red discus, Symphysodon discus Heckel (Osteichthyes: Cichlidae). Braz. J. Biol. 65:609-616.

Cognato D.P. \& Fialho C.B. 2006. Reproductive biology of a population of Gymnotus aff. carapo (Teleostei: Gymnotidae) from southern Brazil. Neotrop. Ichthyol. 4:339-348.

Cruz-Landim C. \& Cruz-Höfling M.A. 2001. Ultrastructure of ovarian follicular epithelium of the Amazonian fish Pseudotylosurus microps (Teleostei: Belonidae): Morphological and histochemical characterization of the intercellular deposits. Revta Bras. Biol. 61:133-140.

Dell A., Morris H.R., Easton R.L., Patankar M. \& Clark G.F. 1999. The glycobiology of gametes and fertilization. Biochem. Biophys. Acta 1473:196-205.

Fausto A.M., Picchietti S., Taddei A.R., Zeni C., Scapigliati G., Mazzini M. \& Abelli L. 2004. Formation of the egg envelope of a teleost, Dicentrarchus labrax (L.): Immunochemical and cytochemical detection of multiple components. Anat. Embryol. 208:43-53.

Favaro L.F., Lopes S.C.G. \& Spach H.L. 2003. Reprodução do peixerei, Atherinella brasiliensis (Quoy et Gaimard) (Atheriniformes, Atherinidae), em uma planície de maré adjacente à gamboa do Baguaçu, Baía de Paranaguá, Paraná, Brasil. Revta Bras. Zool. 20:501-506. 
Gomes B.V.C., Scarpelli R.S., Arantes F.P., Sato Y., Bazzoli N. \& Rizzo E. 2007. Comparative oocyte morphology and early development in three species of trahiras from the São Francisco River basin, Brazil. J. Fish Biol. 70:1412-1429.

Gomes Jr J.L. \& Monteiro L.R. 2007. Size and fecundity variation in populations of Poecilia vivipara Block et Schneider (Teleostei; Poeciliidae) inhabiting an environmental gradient. J. Fish Biol. 71:17991809.

Jalabert B. 2005. Particularities of reproduction and oogenesis in teleost fish compared to mammals. Reprod. Nutr. Rev. 45:261-279.

Karnovsky M.J. 1965. A formaldehyde-glutaraldehyde fixative of high osmolality for use in electron microscopy. J. Cell Biol. 27:137-138.

Lev R. \& Spicer S.S. 1964. Specific staining of sulphate groups with Alcian Blue at low pH. J. Histochem. Cytochem. 12:309.

Lillie R.D. \& Fullmer H.M. 1976. Chemical end groups, p.217-326. In: Lillie R.D. \& Fulmer H.M. (Eds), Histopathologic Technique and Practical Histochemistry. McGraw-Hill, New York.

McManus J.F.A. 1948. Histological and histochemical uses of periodic acid. Stain Technol. 23:99-108.

Matsubara T. \& Sawano K. 1995. Proteolytic cleavage of vitellogenin and yolk proteins during vitellogenin uptake and oocyte maturation in barfin flounder (Verasper moseri). J. Exp. Zool. 272:34-45.

Monroy A., Parisi E. \& Rosati F. 1983. On the segregation of the germ and somatic cell lines in the embryo. Differentiation 23:179-183.

Mowry R.W. 1956. Alcian blue techniques for the histochemical study of acidic carbohydrates. J. Histochem. Cytochem. 4:407-408.

Paffaro Jr V.A., Bizinotto M.C., Joazeiro P.P. \& Yamada A.T. 2003. Subset classification of mouse uterine natural killer cells by DBA lectin reactivity. Placenta 24:479-488.

Parillo F., Fagioli O., Dall'Aglio C. \& Verini-Supplizi A. 2000. Lectin histochemical detection of sulfoglycans in the zona pellucida of mammalian antral oocytes. Acta Histochem. 102:193-202.

Reznick D., Callahan H. \& Llauredo R. 1996. Maternal effects on offspring quality in Poeciliid fishes. Am. Zool. 36:147-156.

Rocha T.L. \& Sabóia-Morais S.M.T. 2007. Células mucossecretoras: origem, diferenciação e secreção durante as fases do desenvolvimento do peixe neotropical Poecilia vivipara (Block et Schneider, 1801) submetido a variações de salinidade. Anais IV Congresso de Pesquisa, Ensino e Extensão, Goiânia, p.1-4.

Sabóia-Moraes S.M.T., Hernandez-Blazquez F.J., Mota D.L. \& Bittencourt A.M. 1996. Mucous cell types in the branchial epithelium of the euryhaline fish Poecilia vivipara. J. Fish Biol. 49:545-548.

Santos J.E., Padilha G.E.V., Bomcompagni-Júnior O., Santos G.B., Rizzo E. \& Bazzoli N. 2006. Ovarian follicle growth in the catfish Iheringichthys labrosus (Siluriformes: Pimelodidae). Tissue Cell 38: 303-310.

Santos R.N., Andrade C.C., Santos A.F.G.N., Santos L.N. \& Araújo F.G. 2005. Histological analysis of ovarian development of the characiform Oligosarcus hepsetus (Cuvier, 1829) in Brazilian reservoir. Braz. J. Biol. 65:169-177.

Santos J.E., Bazzoli N., Rizzo E. \& Santos G.B. 2004. Reproduction of the catfish Iheringichthys labrosus (Lütken) (Pisces, Siluriformes) in Furnas reservoir, Minas Gerais, Brazil. Revta Bras. Zool. 21:193200.

Selman K. \& Wallace R.A. 1989. Cellular aspects of oocyte growth in teleosts. Zool. Sci. 6:211-231.

Spicer S.S. \& Lillie R.D. 1959. Saponificacion as a means of selectively reversing the methylation blockade of tissue basophilia. J. Histochem. Cytochem. 7:123-125.

Spicer S.S., Horn R.G. \& Leppi T.J. 1967. Histochemistry of connective tissue mucopolysaccharides, p.251-303. In: Wagner B.M. \& Smith D.E. (Eds), The Connective Tissue. Williams and Wilkins, Baltimore.

Stehr C.M. \& Hawkes J.W. 1979. The comparative ultrastructure of the egg membrane and associated pore structures in the starry flounder, Platichthys stellatus (Pallas), and pink salmon, Oncorhynchus gorbuscha (Walbaum). Cell Tissue Res. 200:347-356.

Villecco E.I., Mónaco M.E. \& Sánchez S.S. 2007. Ultrastructural changes in the follicular epithelium of Ceratophrys cranwelli previtellogenic oocytes. Zygote 15:273-283.

West G. 1990. Methods of assessing ovarian development in fishes: A review. Aust. J. Mar. Freshwater Res. 41:199-222. 